\title{
HUBUNGAN KUALITAS PRODUK DENGAN KEPUASAN KONSUMEN PADA RESTORAN KOPILAO PUNCAK BOGOR
}

\section{RELATIONSHIP OF PRODUCT QUALITY WITH CUSTOMER SATISFACTION IN BOGOR'S KOPILAO RESTAURANT}

\author{
Rachmat Gunawan $^{1)}$; Deni Azhar ${ }^{2)}$ \\ Program Studi Manajemen Fakultas Ekonomi Universitas Djuanda Bogor \\ e_mail: rachmat.gunawan.fe@unida.ac.id; deniazhar131211@gmail.com
}

\begin{abstract}
This research aims to determine the relationship of product quality with customer satisfaction at Puncak Kopilao Restaurant Bogor. The questionnaire was distributed to 85 respondents. The results of the test validity and reliability show that the statement items are declared valid and reliable and only one statement is invalid. The results of the correlation coefficient analysis state that there is a strong relationship and positive between product quality and consumer satisfaction, with an $R$ value of 0.733. The relationship between product quality and consumer satisfaction at Puncak Bogor Kopilao Restaurant has a strong and positive relationship.
\end{abstract}

Keywords: Product quality, Consumer satisfaction, and Kopilao Puncak Restaurant Bogor.

\begin{abstract}
ABSTRAK
Penelitian ini berguna untuk melihat hubungan kualitas produk dengan kepuasan konsumen pada Restoran Kopilao Puncak Bogor. Kuesioner didistribusikan kepada 85 responden. Desain penelitian deskriptif dan asossiatif. Hasil uji reliabilitas dan validitas menunjukan bahwa butir pernyataan dinyatakan valid dan reliabel dan hanya satu pernyataan tidak valid. Hasil analisis korelasi menyatakan tingkat keeratan atau hubungan yang kuat dan positif, dengan nilai $\mathrm{R}$ sebesar 0,733. Hubungan kualitas produk dengan kepuasan konsumen pada Restoran Kopilao Puncak Bogor memiliki hubungan yang kuat dan positif.

Kata kunci: Kualitas produk, Kepuasan konsumen, dan Restoran Kopilao Puncak
\end{abstract} Bogor 


\section{PENDAHULUAN}

Perkembangan dalam dunia pemasaran mengalami peningkatan, Terutama bisnis di bidang kuliner telah menunjukan perkembangan yang cukup pesat. Hal tersebut ditandai dengan banyaknya berbagai jenis restoran, Ada faktor yang mempengaruhi diantaranya adalah situasi ekonomi Indonesia yang semakin membaik telah mendorong orang untuk memulai usaha baru. Adapun faktorfaktor lain yang juga berpengaruh terhadap perkembangan bisnis restoran adalah gaya hidup, serta kebiasaan masyarakat zaman sekarang. Sehingga meningkatkan tingkat persaingan bisnis dibidang kuliner atau restoran.

Kepuasan konsumen dalam suatu bisnis merupakan kebutuhan, keinginan, dan harapan dari para konsumen yang terpenuhi dan mengkibatkan kesetiaan kepada perusahaan. Jika harapan dari konsumen terpenuhi maka akan merasa puas. Selain itu, bagi perusahaan yang bergerak dibidang kuliner, kualitas produk menjadi suatu hal yang penting, agar menjadi suatu dorongan bagi usaha/bisnis restoran untuk selalu lebih mementingkan produk yang dihasilkan dari segi kualitasnya maupun ragam produknya, dengan adanya kualitas produk yang telah diberikan, maka secara tidak langsung kepuasan konsumen akan terwujud.

Salah satu kunci yang harus dimiliki oleh pengusaha adalah kepuasan konsumen merupakan hal yang selalu diperhatikan oleh perusahaan agar konsumen melakukan pembelian dengan berulang kali, hal tersebut dapat dicapai dengan memperhatikan kualitas produk. Adapun menurut Kotler dan Keller (2016:153) bahwa kepuasan konsumen adalah perasaan kecewa ataupun senang yang dirasakan oleh konsumen setelah menggunakan berbagai pelayanan kinerja yang sesuai maupun tidak sesuai dengan harapannya.

Bisnis yang sangat menjanjikan keuntungannya membuat banyak pihak ingin memulai bisnis kuliner tersebut, tidak terkecuali di daerah Puncak Bogor. Selain Puncak dikenal dengan tempat pariwisata yang khas dengan udaranya yang sejuk, dikenal juga tempat wisata dengan harga yang terjangkau untuk bisa dikunjungi oleh berbagai macam golongan masyarakat di Indonesia. Saat ini Puncak dikenal dengan tempat wisata yang sering dikunjungi di akhir pekan dan terlihat dari kemacetan yang selalu terjadi dan banyaknya pengunjung diakhir pekan. Hal ini menjadikan kondisi dimana peluang bisnis di Puncak semakin besar dengan salah satunya yaitu membuka bisnis kuliner.

Restoran Kopilao Puncak Bogor adalah usaha yang menawarkan jasa kuliner. Didirikan oleh Rimawati pada tahun 2016 dan beralamat di Jalan Raya Puncak No. 299 Cipayung Megamendung, Cisarua-Bogor. Restoran ini menjual berbagai jenis makanan, dan harga dari produk murah dibandingkan dengan hargaharga di restoran lain yang berada di daerah Puncak. Restoran Kopilao Puncak memiliki tempat yang nyaman dan di dalamnya terdapat fasilitas modern yang disukai banyak kalangan muda seperti menyediakan wifi, karaoke gratis, musik, mushola yang nyaman dan design tempat yang unik. Berdasarkan hasil wawancara dengan pengunjung sebanyak tiga puluh orang di Restoran Kopilao Puncak (2019) ada beberapa masalah yang dimana pada siang hari restoran ini selalu sepi pengunjung, dilihat dari sisi harga, rasa makanan, design tempat dan fasilitas semua dirasa cukup, sehingga merasa tertarik untuk mengambil penelitian di Restoran Kopilao Puncak Bogor.

Berdasarkan data jumlah konsumen yang berkunjung ke Restoran Kopilao Puncak Bogor pada bulan September 2018 sampai dengan Agustus 2019 adalah sebagai berikut: 
Tabel 1.1 Jumlah Konsumen Berkunjung Pada Restoran Kopilao Puncak Bogor

\begin{tabular}{lcc}
\hline \multicolumn{1}{c}{ Bulan } & Jumlah Konsumen (Orang) & Perkembangan Konsumen (\%) \\
\hline September 2018 & 400 & - \\
Oktober 2018 & 800 & 100 \\
November 2018 & 450 & $(43,75)$ \\
Desember 2018 & 1.100 & 144,44 \\
Januari 2019 & 500 & $(54,54)$ \\
Februari 2019 & 300 & $(40)$ \\
Maret 2019 & 423 & 41 \\
April 2019 & 450 & 6,38 \\
Mei 2019 & 425 & $(5,56)$ \\
Juni 2019 & 830 & 95,29 \\
Juli 2019 & 600 & $(27,71)$ \\
Agustus 2019 & 532 & $(11,33)$ \\
\hline \multicolumn{1}{c}{ Jumlah $\quad$ Rata-rata } & $\mathbf{6 . 8 1 0}$ & $\mathbf{1 0 5 , 2 2}$ \\
\hline \multicolumn{1}{c}{ (567,5 } & $\mathbf{8 , 7 7}$ \\
\hline
\end{tabular}

Sumber : Restoran Kopilao Puncak Bogor, 2019

Berdasarkan data Tabel 1.1 bahwa perkembangan konsumen rata-rata per bulan yaitu $8,77 \%$ karena penjualan di Restoran Kopilao Puncak Bogor tidak stabil (fluktuasi) bahkan tidak mencapai target yang ditentukan. Jumlah konsumen tertinggi yaitu pada bulan Desember dengan jumlah 1.100 orang, karena saat bulan tersebut kawasan Puncak dipadati oleh orang-orang yang akan pergi berlibur sehingga Restoran Kopilao Puncak menjadi salah satu tempat untuk beristirahat karena lokasi strategis berada di pinggir jalan raya. Sedangkan jumlah konsumen terendah yaitu

pada bulan Februari dengan jumlah 300 orang, karena pada bulan tersebut orang-orang sudah sibuk kembali pada aktivitasnya seperti berkerja dan sekolah, kawasan Puncak pun tidak seramai seperti akhir tahun. Ini menunjukkan pada bulan-bulan tertentu target perusahaan sering tidak tercapai bahkan penurunan yang drastis.

Berikut data rekapitulasi kepuasan konsumen terhadap kualitas produk yang diberikan Restoran Kopilao Puncak Bogor pada tahun 2019:

Tabel 1.2 Rekapitulasi Keluhan Konsumen Pada Restoran Kopilao Puncak Bogor

\begin{tabular}{llccc}
\hline No & Jenis Keluhan & $\begin{array}{c}\text { Jumlah } \\
\text { Konsumen }\end{array}$ & Jumlah Keluhan & Persentase (\%) \\
\hline 1 & $\begin{array}{l}\text { Pelayanan yang kurang } \\
\text { memuaskan (pelayanan) }\end{array}$ & 30 & 23 & 77 \\
2 & $\begin{array}{l}\text { Pesanan terlalu lama datang } \\
\text { (pelayanan) }\end{array}$ & 30 & 19 & 63 \\
\hline 3 & $\begin{array}{l}\text { Tidak sesuainya informasi } \\
\text { yang diberikan dengan apa } \\
\text { yang didapat (kesan kualitas) } \\
\begin{array}{l}\text { Makanan yang tidak sesuai } \\
\text { dengan daftar menu } \\
\text { (kesesuaian) }\end{array}\end{array} \quad 30$ & 26 & 87 \\
\hline
\end{tabular}

Sumber: Data Primer Diolah,2019.

Berdasarkan data Tabel 1.2 tersebut hasil rekapitulasi keluhan dari konsumen Restoran Kopilao Puncak Bogor yaitu ada 23 orang konsumen dari jumlah konsumen 30 diberikan kurang memuaskan, 19 orang mengeluh karena pesanan terlalu lama datangnya, 15 orang menyatakan bahwa Tidak sesuainya informasi yang diberikan dengan apa orang yang menyatakan pelayanan yang yang didapat, dan 26 konsumen mengeluh 
karena makanan yang dipesan tidak sesuai dengan daftar menu. Hal ini memperkuat adanya ketidakpuasan konsumen. Adapun data yang menunjukan tentang pengetahuan konsumen restoran di sekitar wilayah Puncak terhadap Restoran Kopilao Puncak Bogor dilihat dari 30 orang narasumber sebagai berikut:

Tabel 1.3 Data Pra Survey Penilaian Konsumen Terhadap Keberadaan Restoran Kopilao Puncak Bogor

\begin{tabular}{|c|c|c|c|}
\hline No & Pernyataan & Ya & Tidak \\
\hline 1 & 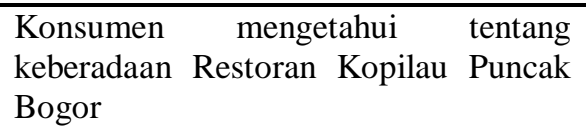 & 21 & 9 \\
\hline 2 & $\begin{array}{l}\text { Konsumen menilai baik Restoran } \\
\text { Kopilao Puncak Bogor. }\end{array}$ & 14 & 16 \\
\hline 3 & $\begin{array}{l}\text { Merasakan puas atas kualitas produk } \\
\text { pada Restoran Kopilao Puncak Bogor }\end{array}$ & 11 & 19 \\
\hline
\end{tabular}

Sumber:Data Primer Diolah, 2019

Berdasarkan data Tabel 1.3 tersebut restoran namun hanya sedikit yang merasakan dapat dilihat sebagian besar konsumen (21 orang) mengetahui keberadaan dan pernah berkunjung ke Restoran Kopilau Puncak Bogor, penilaian Restoran Kopilao Puncak Bogor dinyatakan baik (14 orang) dan konsumen yang merasa puas atas kualitas produk yang disajikan oleh Restoran Kopilao Puncak Bogor (11 orang), sedangkan 19 orang menyatakan tidak puas terhadap kualitas produk yang disajikan oleh Restoran Kopilao Puncak Bogor. Hal ini menunjukan bahwa sebagian besar sudah mengetahui keberadaan kepuasan atas kualitas produk yang diberikan pihak restoran.

Bisnis yang bergerak di bidang kuliner harus bisa memasarkan jasa yang diproduksinya kepada konsumen agar dapat bertahan dan bersaing dengan perusahaan lain. Semakin ketatnya persaingan bisnis yang serupa maka perusahaan harus lebih cepat dalam usaha menarik konsumennya. Adapun data restoran pesaing yang berdekatan dengan Restoran Kopilao Puncak dapat dilihat pada Tabel 1.4 berikut ini:

\section{Tabel 1.4 Restoran Pesaing Kopilao Puncak Bogor}

\begin{tabular}{|c|c|c|c|}
\hline Restoran & Alamat & Kelebihan & Kekurangan \\
\hline Barracks Café & $\begin{array}{l}\text { Jl. Raya Puncak } \\
\text { KM. 79, } \\
\text { Lembah Nyiur, } \\
\text { Kec. Cisarua, } \\
\text { Bogor, Jawa } \\
\text { Barat } 16750\end{array}$ & $\begin{array}{l}\text { 1. Adanya live musik } \\
\text { 2. Menu makanan } \\
\text { beragam } \\
\text { 3. Design tempat yang } \\
\text { menarik } \\
\text { 4. Harga terjangkau }\end{array}$ & $\begin{array}{ll}\text { 1. } & \text { Letak toilet yang terlalu jauh } \\
\text { dari restoran } \\
\text { 2. Tempat yang sempit } \\
\text { 3. Lama dalam menghidangkan } \\
\text { pesanan }\end{array}$ \\
\hline $\begin{array}{l}\text { Breeve Hills Resto } \\
\text { \& Café }\end{array}$ & $\begin{array}{l}\text { Jl. Raya Puncak } \\
\text { No.81, } \\
\text { Leuwimalang, } \\
\text { Kec. Cisarua, } \\
\text { Bogor, Jawa } \\
\text { Barat } 16750\end{array}$ & $\begin{array}{l}\text { 1. Pemandangan yang } \\
\text { megarah langsung } \\
\text { pada gunung dan } \\
\text { bukit }\end{array}$ & $\begin{array}{l}\text { 1. Harga yang relatif mahal } \\
\text { 2. Tempat yang sempit. } \\
\text { 3. Konsumen tidak bisa } \\
\text { berlama-lama karena } \\
\text { restoran yang selalu ramai. }\end{array}$ \\
\hline
\end{tabular}




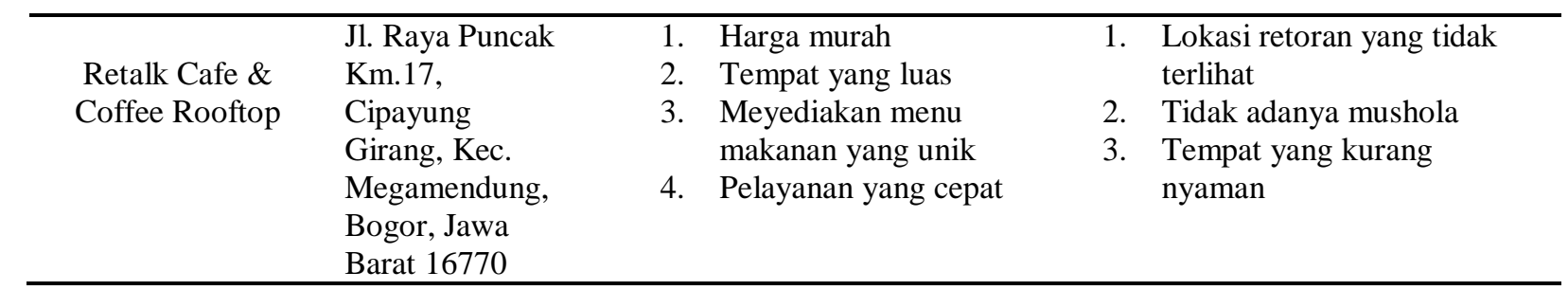

Sumber: Data Primer, 2019.

Berdasarkan data Tabel 1.4 tersebut bahwa letak Restoran Barracks cafe jarak \pm 3,7 km dari Restoran Kopilao Puncak, Breeve Hills Resto \& Cafe $\pm 2,8$ km dari Restoran Kopilao Puncak, Retalk Cafe \& Coffee Rooftop \pm 400 $\mathrm{m}$ dari Restoran Kopilao Puncak, yang ada sekitar Puncak Bogor. Restoran tersebut adalah pesaing dari Restoran Kopilao Puncak Bogor dengan kelebihan dan kekurangan masingmasing. Sehingga Restoran Kopilao Puncak Bogor harus meningkatkan kualitas pelayanan

\section{Materi dan Metode}

\section{Pengertian Kualitas Produk}

Kualitas produk menurut Mowen (2012:61) kualitas produk merupakan proses evakuasi secara keseluruhan kepada konsumen atas perbaikan kinerja suatu produk. Sedangkan menurut Kotler dan Keller (2016:164), kualitas produk adalah kemampuan suatu barang untuk memberikan hasil atau kinerja yang sesuai bahkan melebihi apa yang diiginkan konsumen. Maka kesimpulannya yaitu bahwa kualitas produk adalah merupakan kemampuan suatu produk dalam memenuhi keinginan konsumen dan produk tersebut dapat sesuai dengan standar ukur yang telah ditetapkan.

\section{Pengertian Kepuasan Konsumen}

Pengertian kepuasan konsumen
menurut Lupiyoadi $(2014: 228)$ adalah
seseorang yang menyatakan hasil perbandingan atas kinerja produk atau jasa diterima dengan harapannya. Kepuasan konsumen menurut Tjiptono (2016:312) adalah perasaan setelah membandingkan kinerja antara persepsi yang didapat dengan harapannya. Dapat disimpulkan bahwa kepuasan konsumen merupakan agar dapat bersaing dengan restoran lainnya. Hal ini memperlihatkan bahwa usaha kuliner di Puncak Bogor bersaing diduga disebabkan oleh kualitas produk yang tidak mampu bersaing dan selera konsumen makin cepat berubah maka sebuah perusahaan perlu memahami dan mempelajari bagaimana kualitas produk yang baik. Apabila kualitas produk makanan atau minuman tidak sesuai dengan keinginan konsumen maka produk tersebut tidak akan laku di pasaran.

perasaan yang dirasakan akibat adanya pengaruh hasil kinerja pelayanan atas harapan konsumen terhadap pelayanan suatu perusahaan terhadap konsumen.

\section{Hubungan Kalitas Produk dengan Kepuasan Konsumen}

Produk adalah setiap apa saja yang ditawarkan kepada pasar atau konsumen untuk mendapatkan perhatian, pembelian, pemakaian, atau konsumsi yang dapat memenuhi keinginan atau kebutuhan. Produk yang mempunyai kondisi baik yang akan memuaskan konsumen, begitu sebaliknya jika produk dalam kondisi buruk akan menimbulkan ketidakpusan pada konsumen. Semakin tinggi kualitas produk, maka kepuasaan konsumen akan tinggi pula (Kotler dan Amstrong, 2015:283).

Kualitas produk merupakan bagaimana suatu produk mampu memenuhi harapan konsumen. Hal tersebut akan mempengaruhi kepuasan konsumen, dimana akan merasakan kepuasan jika produk yang ditawarkan memiliki kualitas produk yang baik, begitupun sebaliknya. Kualitas produk merupakan tolak ukur dalam menentukan kepuasan konsumen 
atau tidak. Hubungan kualitas produk dengan kepuasan konsumen diperkuat dalam penelitian yang telah dilakukan oleh Linda Puspitasari (2016) bahwa kualitas produk berpengaruh terhadap kepuasan konsumen dengan kualitas produk yang berkualitas maka keputusan dari banyak konsumen akan berdampak positif dikarenakan kualitas produk memberikan nilai lebih terhadap kepuasan konsumen.

\section{Kerangka Pemikiran}

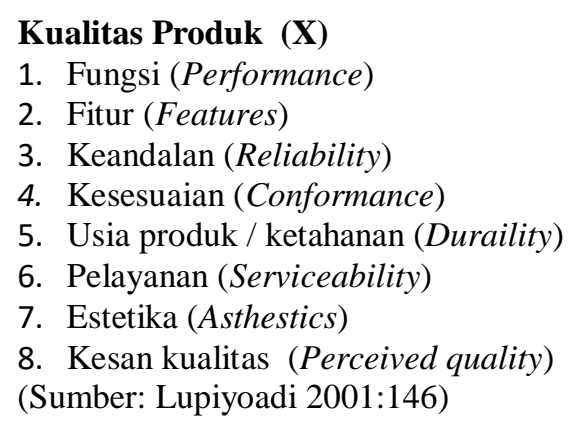

1. Fungsi (Performance)

2. Fitur (Features)

3. Keandalan (Reliability)

4. Kesesuaian (Conformance)

5. Usia produk / ketahanan (Duraility)

6. Pelayanan (Serviceability)

7. Estetika (Asthestics)

8. Kesan kualitas (Perceived quality) (Sumber: Lupiyoadi 2001:146)

\section{Permasalahan Penelitian}

Jumlah konsumen dan data penjualan berfluktuasi, keluhan konsumen tinggi dan pesaing Restoran Kopilao Puncak Bogor banyak sehingga kualitas produk tidak mampu bersaing untuk kepuasan konsumen.

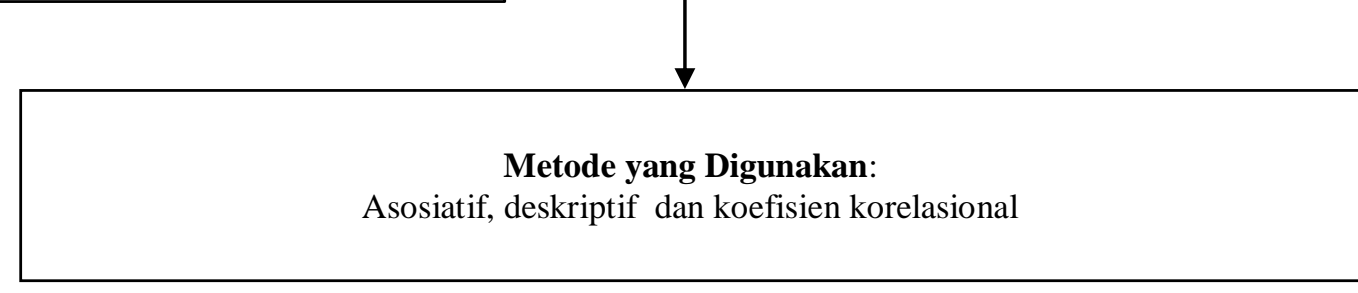

\section{Penelitian Terdahulu:}

1. Kartika Nur Rahmawati (2017)

2. Gracia Sekartaji (2015)

3. Utami Sulistyaningrum (2014)

4. Paula Dinar Widya Pranastiti (2012)

5. Hesti Ayu Pratiwi (2009)

Gambar 2.1 Kerangka Pemikiran

\section{Desain Penelitian}

Desain yang dipakai adalah metode deskriftif dan asosiatif. Menurut Sugiyono (2012:11) menyatakan bahwa pengertian asosiatif adalah penelitian yang bertujuan untuk mengetahui pengaruh ataupun hubungan antara dua variabel atau lebih. Untuk mengetahui ada atau tidaknya hubungan kualitas produk dengan kepuasan konsumen pada Restoran Kopilao
Puncak Bogor. Menurut Umar (2008:5) penelitian deskriptif yaitu menggambarkan apa yang dilakukan perusahaan berdasarkan faktor yang ada untuk diolah menjadi data dan dianalisis untuk memperoleh kesimpulan.

\section{Operasionalisasi Variabel}

Variabel yang diteliti adalah variabel bebas (independent variable), yaitu Kualitas Produk dan variabel tergantung/terikat 
(dependent variable) dalam penelitian ini adalah Kepuasan Konsumen.

Tabel 1.5 Operasionalisasi Variabel Penelitian

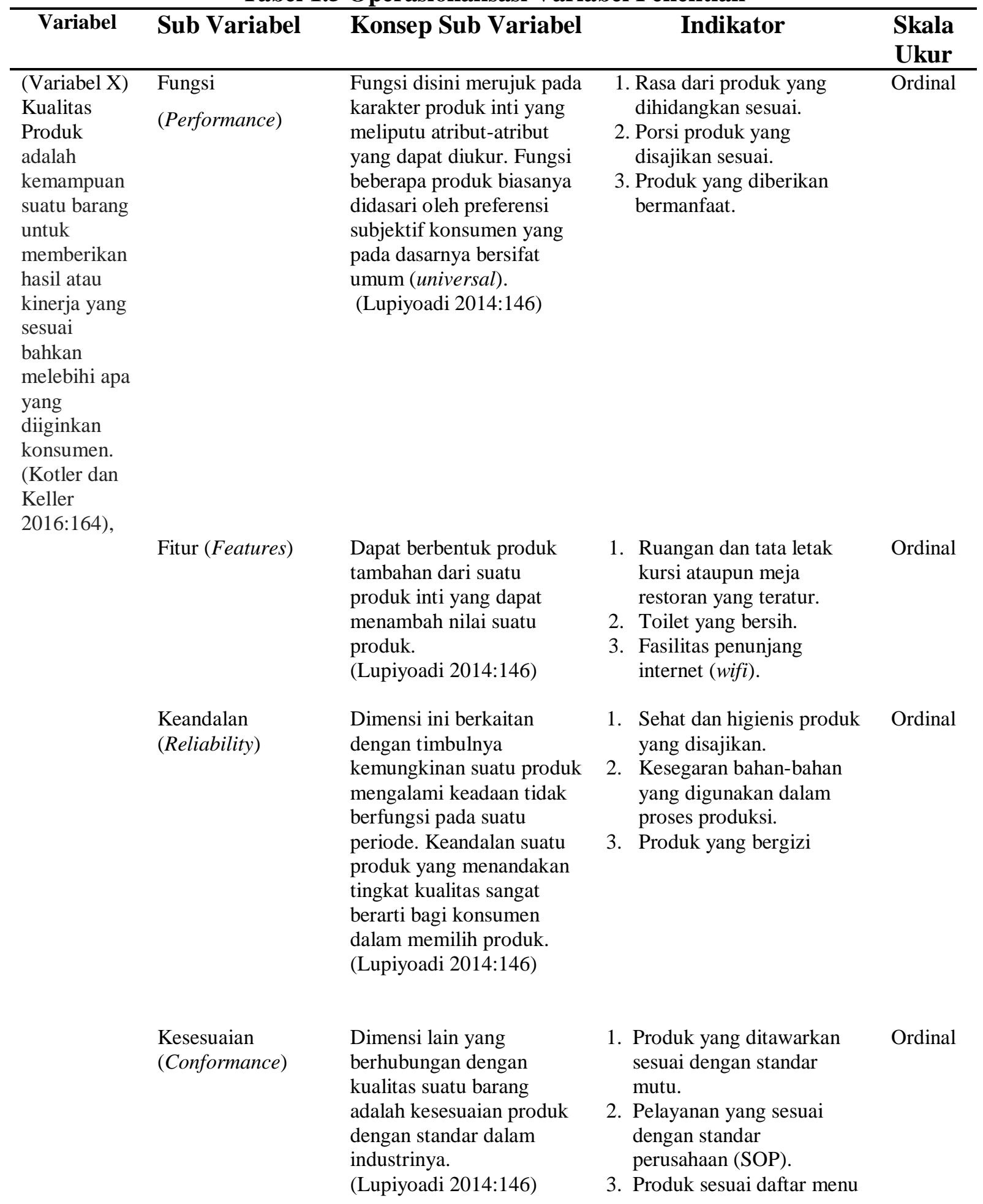




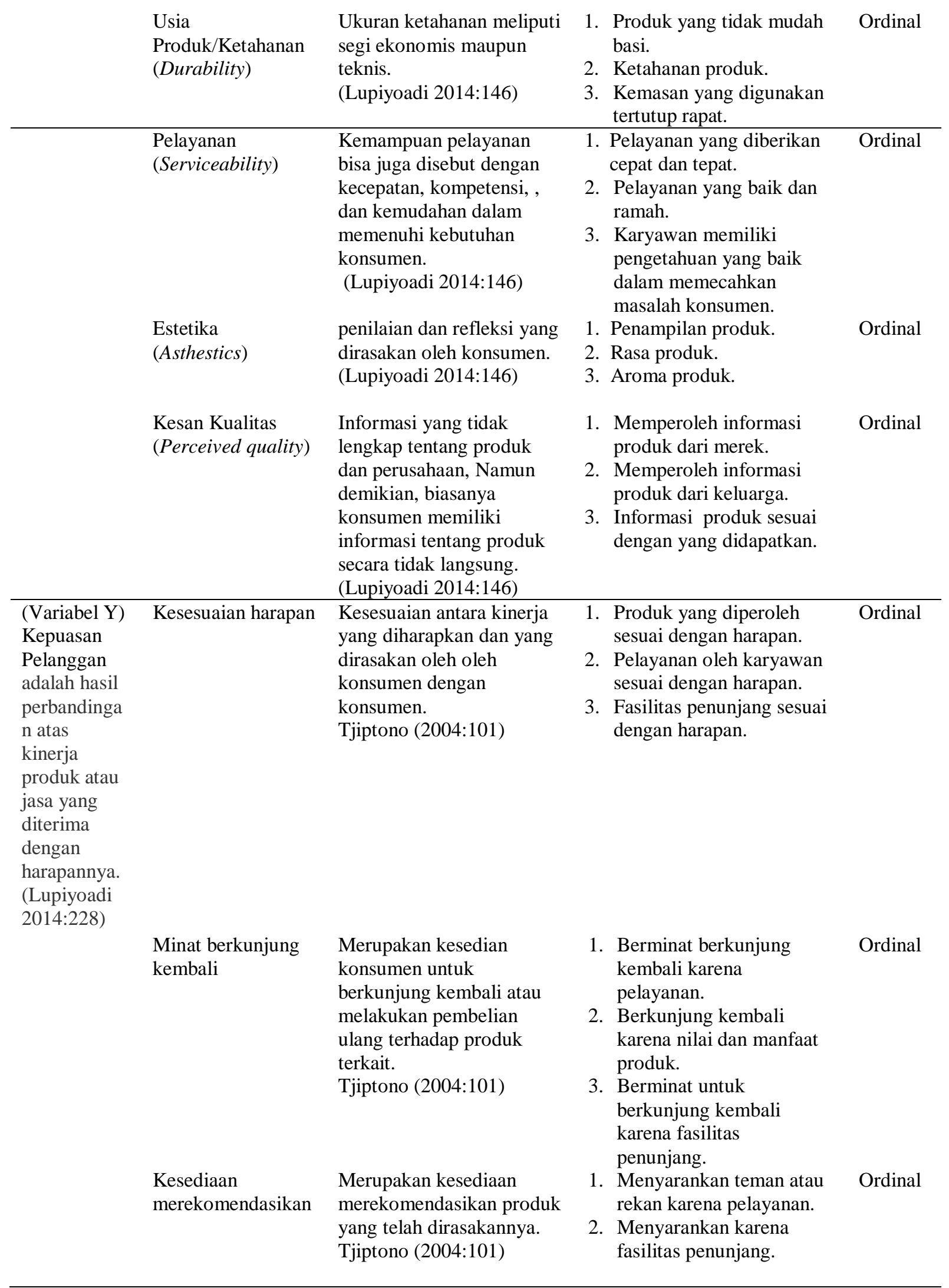




\section{Menyarankan teman} karena manfaat yang didapat setelah mengkonsumsi sebuah produk.

\section{Metode Pengujian Data}

\section{Uji Validitas}

Menurut Sumarsono (2004:291) sebuah instrumen dikatakan valid jika mampu mengukur apa yang diinginkan dari variabel yang diteliti secara benar. Uji dilakukan menggunakan teknik korelasi product moment.

\section{Uji Reliabilitas}

Menurut Sumarsono (2004:291) pengujian realibilitas adalah alat ukur yang dimaksudkan untuk menunjukan sejauh mana alat ukur dapat dipercaya. Dalam penelitian ini Cronchbach's Alpha lebih besar dari nilai ketetapan minimal yaitu 0,6. Hal ini menunjukan bahwa seluruh indikator di dalam setiap variabel tersebut dinyatakan reliabel.

\section{Karakteristik Konsumen}

Menggunakan teknik kuesioner dengan cara menyebarkan kuesioner kepada konsumen Restoran Kopilao Puncak Bogor. Untuk mendapatkan data yang diperlukan dengan melibatkan 85 konsumen sebagai sampel penelitian.

Tabel 1.8 Rekapitulasi Karakteristik Konsumen

\begin{tabular}{cllcc}
\hline No & Karakteristik & \multicolumn{1}{c}{ Ciri-ciri Konsumen } & Jumlah Konsumen (Orang) & Persentase (\%) \\
\hline 1 & Jenis Kelamin & Perempuan & 48 & 56 \\
2 & Usia & 26-35 tahun & 41 & 48 \\
3 & Pendidikan Terakhir & SMA & 33 & 39 \\
4 & Status Pernikahan & Belum menikah & 44 & 52 \\
5 & Pendapatan & Rp 2.100.000 - Rp 3.000.000 & 32 & 38 \\
6 & Pekerjaan & Karyawan swasta & 26 & 32 \\
\hline
\end{tabular}

Sumber : Data Diolah, 2019

Berdasarkan Tabel 1.8 menunjukan bahwa sebagian besar konsumen perempuan dengan jumlah 48 orang atau $56 \%$, di kisaran usia 26-35 tahun dengan jumlah 41 orang atau $48 \%$, dengan pendidikan terakhir SMA dengan jumlah 33 orang atau 39\%, sebagian besar belum menikah dengan jumlah 44 orang atau $52 \%$. Sedangkan penghasilan per tahun $\mathrm{Rp}$ 2.100.000 - Rp 3.000.000 dengan jumlah 32 orang atau $38 \%$ serta karyawan swasta dengan jumlah 26 orang atau $32 \%$.

\section{Tanggapan Konsumen Terhadap Kualitas Produk dan Kepuasan Konsumen pada Restoran Kopilao Puncak Bogor Kualitas Produk}

Adapun rekapitulasi penilaian konsumen terhadap kualitas produk berikut ini:

Tabel 1.9 Rekapitulasi Tanggapan Konsumen Mengenai Kualitas Produk

\begin{tabular}{clccl}
\hline No & \multicolumn{1}{c}{ Pernyataan } & Skor & Kriteria & \multicolumn{1}{c}{ Interprestasi } \\
\hline 1 & Rasa yang enak & 3,97 & Baik & Rasa produk yang enak sesuai dengan selera konsumen. \\
2 & Porsi sesuai & 3,91 & Baik & Porsi makanan yang sesuai konsumen. \\
3 & Ruangan teratur & 3,87 & Baik & Ruangan yang teratur dan rapi memberikan kesan kenyamanan. \\
4 & Toilet bersih & 3,89 & Baik & Toilet yang sesalu dijaga kbersihannya dan tidak jorok. \\
5 & Fasilitas internet baik & 3,94 & Baik & Fasilitas penunjang yang baik membuat konsumen puas. \\
6 & Produk sehat dan higienis & 3,81 & Baik & $\begin{array}{l}\text { Produk yang sehat dah higienis membuat konsumen merasa } \\
\text { tidak perlu khawatir. }\end{array}$ \\
\hline
\end{tabular}




\begin{tabular}{|c|c|c|c|c|}
\hline 7 & Menggunakan bahan segar & 3,92 & Baik & $\begin{array}{l}\text { Bahan yang dijamin kesegaranya membuat konsumen merasa } \\
\text { tenang. }\end{array}$ \\
\hline 8 & Produk bergizi & 3,88 & Baik & $\begin{array}{l}\text { Kandungan gizi dari produk dapat dilihat dari bahan yang } \\
\text { digunakan. }\end{array}$ \\
\hline 9 & Produk sesuai standar mutu & 3,84 & Baik & $\begin{array}{l}\text { Produk yang sudah standar dan cara masak yang sudah } \\
\text { memenuhi standar. }\end{array}$ \\
\hline 10 & Pelayanan sesuai SOP & 3,81 & Baik & $\begin{array}{l}\text { Pelayanan yang sudah memenuhi standar SOP yang telah } \\
\text { ditentukan. }\end{array}$ \\
\hline 11 & Menu sesuai daftar & 3,68 & Baik & Menu yang ditawarkan sesuai pada tampilan pada menu. \\
\hline 12 & Produk tidak mudah basi & 3,78 & Baik & $\begin{array}{l}\text { Produk tidak mudah basi karna menggunakan bahan berkualitas } \\
\text { dan disimpan dalam kulkas. }\end{array}$ \\
\hline 13 & Produk dapat bertahan lama & 3,80 & Baik & Produk dapat bertahan lama apabila disimpan dalam kulkas \\
\hline 14 & Dikemas dengan rapat & 3,78 & Baik & Dapat dibawa kemana saja karna kemasan yang tertutup rapat. \\
\hline 15 & $\begin{array}{l}\text { Melayani dengan cepat dan } \\
\text { tepat }\end{array}$ & 3,48 & Baik & $\begin{array}{l}\text { Pelayan yang sigap yang siap memenuhi kebutuhan yang } \\
\text { diperlukan oleh konsumen. }\end{array}$ \\
\hline 16 & Pelayanan baik dan ramah & 3,62 & Baik & $\begin{array}{l}\text { Keramahan para pelayan yang memberikan kenyamanan pada } \\
\text { hati konsumen. }\end{array}$ \\
\hline 17 & $\begin{array}{l}\text { Memiliki pengetahuan yang } \\
\text { baik }\end{array}$ & 3,75 & Baik & $\begin{array}{l}\text { Pengetahuan yang cukup tentang restoran agar memudahkan } \\
\text { konsumen jika kebingungan. }\end{array}$ \\
\hline 18 & Tampilan menarik dan unik & 3,68 & Baik & $\begin{array}{l}\text { Tampilan yang menarik dan unik menjadi daya tarik bagi } \\
\text { konsumen. }\end{array}$ \\
\hline 19 & Rasa yang enak & 3,64 & Baik & Rasa yang diberikan enak d lidah para konsumen. \\
\hline 20 & Aroma yang enak & 3,75 & Baik & Aroma yang dapat menggugah selera makan. \\
\hline 21 & $\begin{array}{l}\text { Memperoleh informasi dari } \\
\text { merek }\end{array}$ & 3,80 & Baik & $\begin{array}{l}\text { Konsumen memperoleh informasi dari merek karena promosi } \\
\text { yang terus digencar lewat sosial media. }\end{array}$ \\
\hline 22 & $\begin{array}{l}\text { Memperoleh informasi dari } \\
\text { keluarga }\end{array}$ & 3,94 & Baik & $\begin{array}{l}\text { Memperoleh informasi dari keluarga yang sudah berkunjung } \\
\text { sebelumnya. }\end{array}$ \\
\hline 23 & Sesuai dengan yang didapat & 3,83 & Baik & Produk yang sesuai para konsumen. \\
\hline & $\begin{array}{l}\text { Tanggapan konsumen } \\
\text { terhadap kualitas produk }\end{array}$ & 3,79 & Baik & $\begin{array}{l}\text { Kualitas produk sudah baik memiliki rasa enak, porsi } \\
\text { sesuai, fasilitas internet baik, menggunakan bahan segar, } \\
\text { dan memperoleh informasi dari keluarga. }\end{array}$ \\
\hline
\end{tabular}

Sumber : Data Diolah, 2019

Berdasarkan data Tabel 1.9 di atas

konsumen, sedangkan nilai terendah yaitu 3,48 diketahui bahwa penilaian konsumen pada kualitas produk dapat disimpulkan konsumen Restoran Kopilao Puncak Bogor mempunyai rata-rata yaitu 3,79 , nilai tertinggi yaitu 3,97 dengan kriteria baik karena produk restoran dirasakan enak dan sesuai dengan selera dengan kriteria baik karena konsumen masih merasa kurang dilayani dengan cepat dan tepat.

\section{Kepuasan Konsumen (Y)}

Adapun rekapitulasi penilaian terhadap kepuasan konsumen sebagai berik

Tabel 1.10 Rekapitulasi Tanggapan Konsumen Mengenai Kepuasan Konsumen

\begin{tabular}{llccl}
\hline No & \multicolumn{1}{c}{ Pernyataan } & Skor & Kriteria & \multicolumn{1}{c}{ Interprestasi } \\
\hline 1 & Produk sesuai harapan & 3,52 & Tinggi & $\begin{array}{l}\text { Produk yang diberikan sudah sesuai harapan. } \\
2\end{array}$ \\
Pelayanan sesuai harapan & 3,60 & Tinggi & $\begin{array}{l}\text { Pelayanan yang diberikan oleh para karyawan sesuai } \\
\text { dengan harapan konsumen. }\end{array}$ \\
3 & Fasilitas sesuai harapan & 3,71 & Tinggi & $\begin{array}{l}\text { Fasilitas penunjang yang telah disediakan sesuai } \\
\text { dengan yang diharapkan. }\end{array}$
\end{tabular}




\begin{tabular}{|c|c|c|c|c|}
\hline 4 & Berkunjung kembali karena karyawan & 3,72 & Tinggi & $\begin{array}{l}\text { Berminat berkunjung kembali karena karyawan yang } \\
\text { telah memberikan pelayanan yang baik. }\end{array}$ \\
\hline 5 & Berkunjung kembali karena produk & 3,76 & Tinggi & $\begin{array}{l}\text { Produk dari restoran yang membuat konsumen ingin } \\
\text { berkunjung kembali. }\end{array}$ \\
\hline 6 & Berkunjung kembali karena fasilitas & 3,76 & Tinggi & $\begin{array}{l}\text { Minat berkunjung kembali karena fasilitas yang } \\
\text { diberikan membuat konsumen merasa puas. }\end{array}$ \\
\hline 7 & Menyarankan teman karena pelayanan & 3,47 & Tinggi & $\begin{array}{l}\text { Merekomendasikan atau menyarankan kepada teman } \\
\text { untuk mengunjungi restoran karena pelayanan cukup } \\
\text { baik. }\end{array}$ \\
\hline 8 & Menyarankan teman karena fasilitas & 3,62 & Tinggi & $\begin{array}{l}\text { Merekomendasikan atau menyarankan kepada teman } \\
\text { untuk mengunjungi restoran karena fasilitas } \\
\text { penunjang yang diberikan pihak restoran membuat } \\
\text { konsumen puas. }\end{array}$ \\
\hline 9 & Menyarankan teman karena produk & 3,72 & Tinggi & $\begin{array}{l}\text { Produk yang ditawarkan membuat konsumen ingin } \\
\text { juga untuk menyarankan kepada teman-teman nya. }\end{array}$ \\
\hline & $\begin{array}{l}\text { Tanggapan konsumen terhadap } \\
\text { kepuasan konsumen }\end{array}$ & 3,65 & Tinggi & $\begin{array}{l}\text { Kepuasan konsumen tinggi dengan fasilitas } \\
\text { restoran sesuai harapan, berminat berkunjung } \\
\text { kembali karena karyawan, produk, fasilitas,dan } \\
\text { menyarankan teman karena produk. }\end{array}$ \\
\hline
\end{tabular}

Sumber : Data Diolah, 2019

Berdasarkan Tabel 1.10 di atas merekomendasikan restoran kepada teman atau diketahui bahwa penilaian konsumen pada rekannya jika dilihat dari pelayanan yang kepuasan dapat disimpulkan konsumen dilakukan oleh pihak Restoran Kopilao Puncak Restoran Kopilao Puncak Bogor mempunyai rata-rata 3,65, nilai tertinggi yaitu 3,76 dengan kriteria tinggi karena nilai dan manfaat produk yang dihasilkan dan juga fasilitas yang memadai di Restoran Kopilao Puncak Bogor membuat konsumen berminat untuk berkunjung kembali, sedangkan nilai terendah yaitu 3,47 dengan kriteria tinggi karena Bogor.

\section{Hubungan Kualitas Produk dengan Kepuasan Konsumen}

Besarnya kolerasi atau hubungan antara variabel independen yaitu kualitas produk (X) dengan variabel dependen kepuasan konsumen (Y) adalah dengan melihat nilai $\mathrm{R}$.

konsumen masih merasa kurang untuk

Tabel 1.11 Hasil Koefisien Korelasi Correlations

\begin{tabular}{|c|c|c|c|}
\hline & & Kualitas Produk & $\begin{array}{l}\text { Kepuasan } \\
\text { Konsumen }\end{array}$ \\
\hline \multirow[t]{3}{*}{ Kualitas Produk } & Pearson Correlation & 1 &, $733^{* \star}$ \\
\hline & Sig. (2-tailed) & &, 000 \\
\hline & $\mathrm{N}$ & 85 & 85 \\
\hline \multirow[t]{3}{*}{ Kepuasan Konsumen } & Pearson Correlation &, $733^{* \star}$ & 1 \\
\hline & Sig. (2-tailed) & ,000 & \\
\hline & $\mathrm{N}$ & 85 & 85 \\
\hline
\end{tabular}

Berdasarkan Tabel 1.11 di atas hasil perhitungan statistik tersebut dapat diketahui nilai R sebesar 0,733 yang menunjukan korelasi atau hubungan dari variabel independen yaitu kualitas produk $(\mathrm{X})$ dengan variabel dependen yaitu kepuasan pelanggan (Y) memiliki korelasi yang kuat dan positif $(0,60-0,799)$. Artinya semakin baik kualitas produk maka semakin tinggi kepuasan konsumen. 


\section{KESIMPULAN DAN IMPLIKASI}

\section{Kesimpulan}

Berdasarkan hasil penelitian dan pembahasan yang dikemukakan dalam penelitian maka disimpulkan sebagai berikut :

1. Tanggapan konsumen terhadap kualitas produk dan kepuasan konsumen pada Restoran Kopilao Puncak :

a. Penilaian tertinggi kualitas produk pada indikator makanan dan minuman di Restoran Kopilao Puncak Bogor memiliki rasa yang enak, sedangkan nilai terendah pada indikator karyawan Restoran Kopilao Puncak Bogor melayani dengan cepat dan tepat. Tanggapan konsumen Restoran Kopilao Puncak Bogor rata-rata menyatakan kualitas produk baik.

b. Penilaian tertinggi kepuasan konsumen pada indikator berkunjung kembali karena fasilitas yang disediakan sangat lengkap dan nilai dan manfaat yang diperoleh setelah mengkonsumsi produk. Sedangkan nilai terendah pada indikator menyarankan kerabat untuk membeli produk karena pelayanan yang memuaskan. Tanggapan konsumen Restoran Kopilao Puncak Bogor rata-rata menyatakan kepuasan konsumen tinggi.

2. Hubungan Kualitas Produk dengan Kepuasan Konsumen pada Restoran Kopilao Puncak Bogor menunjukan tingkat hubungan yang kuat dan positif.

\section{Implikasi}

Adapun implikasi yang diberikan sebagai berikut :

1. Restoran Kopilao Puncak Bogor dapat meningkatkan tanggapan konsumen mengenai kualitas produk salah satunya dengan meningkatkan pelayanan dan karyawan Restoran Kopilao Puncak Bogor dituntut untuk lebih cepat dan tepat dalam melayani kebutuhan konsumen merasa dilayani dengan baik.
2. Dalam memuaskan konsumen sebaiknya pihak restoran Kopilao Puncak Bogor lebih meningkatkan pelayanan dan diharapkan konsumen berkunjung kembali merekomendasikan kepada teman ataupun kerabat untuk berkunjung ke Restoran Kopilao karena pelayanan dari pihak restoran membuat konsumen merasa puas.

3. Bagi peneliti selanjutnya sebaiknya menambah sampel dan lokasi penelitian yang lain serta menambah variabel bebas lainnya seperti kualitas pelayanan, emosional, harga, dan biaya.

\section{UCAPAN TERIMA KASIH}

Ucapan terima kasih kepada Restoran Kopilao Puncak Bogor.

\section{DAFTAR PUSTAKA}

Kotler, Philip dan Gary Armstrong. 2015. Marketing an Introducing Prentice Hall twelfth edition. Pearson Education. Inc: England.

Kotler, Phillip dan Kevin Lane Keller. 2016. Manajemen Pemasaran. edisi 12 Jilid 1 \& 2. Jakarta. PT. Indeks.

Linda Puspitasari. 2016. Pengaruh Kualitas Produk dan Kualitas Pelayanan Terhadap Kepuasan pelanggan, Skripsi sarjana. Fakultas Ekonomi dan Bisnis Islam Institut Agama Islam Negeri Purwokerto. (http://repository.iainpurwokerto.ac.id/66

7) diakses pada Rabu tanggal 3 Juli 2019 pukul 08.30.

Lupiyoadi, Rambat. 2014. Manajemen Pemasaran Jasa. Edisi 3. Jakarta. Salemba Empat

Mowen, John C. 2012. Perilaku Konsumen dialih bahasakan oleh Dwi Kartika Yahya. Jakarta. Erlangga.

Sugiyono. 2012. Metode Penelitian Kuantitatif Kualitatif dan R\&D. Bandung. Alfabeta.

Suharsimi, Arikunto. 2010. Prosedur Penelitian Suatu Pendekatan Praktek. Jakarta. Rineka Cipta. 
Sumarsono, Sonny. 2004. Metode Riset Sumber Daya Manusia. Yogyakarta. Graha Ilmu.

Tjiptono, Fandy. 2016. Pemasaran Jasa Prinsip, Penerapan dan Penelitian. Yogyakarta. CV Andi Offset.
Umar, Husain. 2008. Metode Untuk Penelitian Skripsi dan Tesis Bisnis. PT. Rajagrafindo Persada. Jakarta. 